\title{
Content of the term "corruption" in international criminal law
}

\section{L. Blashkova ${ }^{1}$}

${ }^{1}$ Ugra State University, 16 Chekhova str., Khanty-Mansiysk 628012, Russian Federation

DOI: 10.18255/1996-5648-2021-2-242-247

Research article Full text in Russian

The development of the processes of international integration and cooperation has led to the need to develop common rules for interstate interaction aimed at combating corruption crimes that pose a threat not only to national but also to international interests. This paper presents an analysis of the provisions of a number of sources of modern international criminal law on combating corruption. Attention is drawn to the absence in modern international law of a qualitatively formulated definition of corruption, as well as a system of its legally significant features. The absence of this definition creates difficulties in defining a strictly defined list of types of corruption crimes both in international and national criminal law.

Keywords: corruption; corruption crimes; international criminal law; legal signs of corruption; anti-corruption activities; UN Convention against Corruption

\section{INFORMATION ABOUT AUTHORS}

\author{
Blashkova, Ludmila L. | E-mail: blashkovaugra@yandex.ru \\ Senior Lecturer
}




\section{Содержание термина «коррупция» в международном уголовном праве}

\section{Л. Л. Блашкова ${ }^{1}$}

${ }^{1}$ Югорский государственный университет, ул. Чехова, 16, Ханты-Мансийск, 628012 , Российская Федерация

DOI: $10.18255 / 1996-5648-2021-2-242-247$

УДК 343.3

Научная статья

Полный текст на русском языке

Развитие процессов международной интеграции и сотрудничества привело к необходимости выработки общих правил межгосударственного взаимодействия, направленного на борьбу с коррупционными преступлениями, представляющими опасность не только для национальных, но и для международных интересов. В настоящей работе представлен анализ положений ряда источников современного международного уголовного права о противодействии коррупции. Обращается внимание на отсутствие в современном международном праве качественно сорормулированного определения коррупции, равно как и системы ее юридически значимых признаков. Отсутствие данной дефиниции порождает трудности установления как в международном, так и в национальном уголовном праве строгого перечня конкретных видов коррупционных преступлений.

Ключевые слова: коррупция; коррупционные преступления; международное уголовное право; юридические признаки коррупции; антикоррупционная деятельность; Конвенция ООН против коррупции

\section{ИНФОРМАЦИЯ ОБ АВТОРАХ}

Блашкова, Людмила Леонидовна $\mid$ E-mail: blashkovaugra@yandex.ru

Старший преподаватель

Высокая общественная опасность коррупции была известна ещё в эпоху Древнего мира. По мнению отдельных исследователей, высокоорганизованная коррупция стала действительной причиной уничтожения многих некогда процветающих античных государств [1; 2, с. 1074]. Однако достаточно продолжительный период мировой истории каждое государство пыталось решить проблему противодействия коррупции собственными силами, используя преимущественно уголовно-правовые и административные средства. Ситуация стала принципиально меняться вследствие развития буржуазных отношений и международного сотрудничества в экономи-

(с) Блашкова Л. Л., 2021

Статья открытого доступа под лицензией CC BY (https://creativecommons.org/licenses/by/4.0/) 
Блашкова Л. Л.

ческой, военной, культурной и иных сферах деятельности. Эффективность обеспечения прав и законных интересов представителей различных сторон в международных отношениях стала иметь основополагающее значение в межгосударственных интеграционных процессах.

Международное право в области противодействия коррупции в настоящее время включает в себя значительное количество источников, принимаемых со второй половины XX века. Их анализ позволяет классифицировать все нормативные акты международного антикоррупционного законодательства на 1) общие; 2) региональные; 3) локальные (двусторонние).

Безусловно, наибольшее правовое значение, в т. ч. в области международно-правовой регламентации противодействия коррупции, имеют источники первой группы, которая включает в себя акты международного права, принятые в результате деятельности Организации Объединённых Наций (далее - ООН) - международной организацией, в состав которой входит наибольшее количество государств - субъектов международных отношений. Общий характер международные нормативные акты, принимаемые Генеральной Ассамблеей ООН, носят также в связи с глобальностью целей, ради достижения которых создана и функционирует эта организация: поддержание международного мира и обеспечение безопасности; развитие дружеских отношений между нациями; осуществление всеобщего международного сотрудничества и т. д. [3].

В части обеспечения безопасности и развития международного сотрудничества Генеральной Ассамблеей $\mathrm{OOH} \mathrm{приняты} \mathrm{два} \mathrm{специальных}$ нормативных акта о противодействии коррупции. Первым из них является Декларация от 16.12.1996 о борьбе с коррупцией и взяточничеством в международных коммерческих операциях. Несмотря на всеобщий характер положений данного акта, для каждого государства, принявшего на себя обязательство по соблюдению его положений, а также для всех государств, которые являются участниками иных международных и региональных объединений, всё же он носит узкопрофильный характер, поскольку распространяет своё действие лишь на субъектов международной коммерческой деятельности [4].

Применительно к раскрытию содержания коррупции указанная Декларация не может признаваться источником, характеризующимся высоким техническим качеством нормативных предписаний. Толкование её норм позволяет сделать вывод о разнородности понятий «коррупция» и «взяточничество», хотя в действительности последнее является составной частью коррупции. В целом данный нормативный акт содержит описание общих направлений деятельности государств по предупреждению и профилактике «всех фрорм коррупции, взяточничества и связанных с ними противоправных действий в международных коммерческих организациях» [4]. Разработчики рассматриваемой декларации оставили разрешение 
вопросов о содержании коррупции, преступлений и иных правонарушений, имеющих коррупционный характер, представителям законодательных органов власти государств - участников ООН.

Универсальным нормативным актом, определяющим основные начала противодействия коррупции во всём мировом сообществе, является заключенная в г. Нью-Йорк Конвенция ООН от 31.10.2003 против коррупции [5-6] (далее - Конвенция). В ст. 2 Конвенции содержатся имеющие юридическое значение термины, которые используются в тексте иных норм и, очевидно, должны быть имплементированы в законодательство тех государств, которые признали для себя обязательность положений этого международного акта. Судя по названию, коррупция является тем социально опасным явлением, для обеспечения регламентации противодействия которому и была разработана Конвенция ООН 2003 года. Но определения «коррупция» или «коррупционное преступление» Конвенция не содержит, что не позволяет однозначно решить вопрос о содержании указанных правовых категорий.

Бесспорная юридическая ценность Конвенции, которая многими исследователями признаётся в качестве основополагающего нормативного акта международного права в области борьбы с коррупцией [7, с. 96; 8, с. 34; 9, с. 71-72], заключается в обозначении круга криминализируемых деяний, содержащих в себе признаки данного социально негативного явления. Виды данных посягательств перечислены в статьях гл. 3 Конвенции «Криминализация и правоохранительная деятельность». Но с учётом недопустимости нарушения суверенитета государств, ратифицировавших Конвенцию, содержание норм, закрепляющих виды преступных посягательств, носит общий ориентирующий характер и не раскрывает всех юридически значимых признаков составов коррупционных преступлений. Так, в соответствии с Конвенцией видами криминальных деяний, формирующих основу коррупции, признаются следующие: подкуп (ст. 15, 16, 21), хищение или иное нецелевое использование имущества (ст. 17, 22), злоупотребление влиянием (ст.18) или служебным положением (ст. 19), незаконное обогащение (ст. 20), легализация преступных доходов (ст. 23), сокрытие (ст. 24), воспрепятствование осуществлению правосудия (ст. 25). Перечень видов коррупционных посягательств, криминализация которых необходима для выполнения обязательств, взятых государствами при ратификации Конвенции, является исчерпывающим.

Выше мы указали, что приведенные нормативные акты ООН являются специальными источниками международного антикоррупционного права. Но было бы неверным оставить без внимания Конвенцию ООН от 15.11.2000 против транснациональной организованной преступности, принятую в г. Нью-Йорке. Этот нормативный акт не является специальным документом, регламентирующим организацию международного противодействия 
Блашкова Л. Л.

коррупционной преступности, но и его нормами частично раскрывают содержание рассматриваемого явления. Так, в ст. 8 Конвенции от 15.11.2000 определены правила криминализации коррупции - действий, которые составляют сущность данного социально опасного явления. Толкование положений приведённой нормы позволяет признать наличие коррупционной составляющей в таких умышленно совершаемых деяниях, как:

а) обещание, предложение или предоставление публичному должностному лицу «неправомерного преимущества» в обмен на совершение этим должностным лицом какого-либо действия или бездействия при выполнении своих служебных обязанностей;

б) вымогательство или принятие должностным лицом «неправомерного преимущества» в обмен на совершение какого-либо действия или бездействия при выполнении своих служебных обязанностей;

в) аналогичные перечисленным действия, которые совершаются иностранным публичным должностным лицом или международным гражданским служащим;

г) иные действия, которые в соответствии с Конвенцией ООН от 15.11.2000 каждое ратифицировавшее ее государство готово признать в качестве «других фрорм» коррупционных преступлений [10, с. 3-33].

Учитывая изложенное, можно констатировать, что в международных актах ООН, возможность ратификации которых предоставлена всем представителям международного сообщества, не содержится определения коррупции как социально опасного явления и обобщающей правовой дефиниции коррупционного преступления. В приведённых нормативных актах описываются лишь частные случаи коррупционного поведения, отдельные признаки составов преступлений, фрормирующих коррупцию. Дополнительно обращает на себя внимание использование законодательного приёма открытого перечня деяний, которые могут быть признаны в качестве коррупционных преступлений на уровне национального права, а могут и не признаваться таковыми законодателем конкретной страны.

С учетом специфики фрункций международного права это в принципе не может привести к блокированию антикоррупционной деятельности на уровне отдельного государства, ратифицировавшего соответствующие конвенции, равно как и к невозможности осуществления международного (межгосударственного) сотрудничества в области противодействия коррупции. Соблюдение принципов невмешательства во внутренние дела и уважения государственного суверенитета не позволяют ни ООН, ни иным международным организациям навязывать участникам международных отношений строго определённый перечень видов преступлений, которые обязательно должны были бы быть признанными коррупционными на уровне национального уголовного права. В этой части международ- 
ное право выполняет только ориентирующую фрунццию для законодателя, представляющего государство - члена международного сообщества.

В то же время качественно сорормулированное и закреплённое в нормах международного права определение коррупции, установление закрытого перечня её юридически значимых признаков обеспечило бы добротную юридическую основу для единообразного понимания сущности коррупции и фриксации видов коррупционных преступлений на уровне национального права. Согласованность норм международного и национального права, в свою очередь, обеспечило бы повышение степени эффективности противодействия коррупции, включая международное сотрудничество в области антикоррупционной деятельности.

\section{Ссылки}

1. Моммзен Т. История Рима: в 5 т. Т. 2, кн. 4 / под общ. ред. Н. А. Машкина. M.: Гос. социально-эконом. изд-во, 1937. URL: http://ancientrome.ru/publik/article. htm?a=1292333981 (дата обращения: 20.12.2020).

2. Tarn W, Griffith G. Hellenistic Civilization. London, 1952. 1090 c.

3. Устав Организации Объединённых Наций: принят в Сан-Франциско 26 июня 1945 года. URL: https://www.un.org/ru/charter-united-nations/index.html (дата обращения: 20.12.2020).

4. Декларация Организации Объединённых Наций о борьбе с коррупцией ивзяточничествомв международных коммерческихоперациях:принята Резолюцией № 51/191 Генеральной Ассамблеи от 16 декабря 1996 года. URL: https://www.un.org/ ru/documents/decl_conv/declarations/bribery.shtml (дата обращения: 20.12.2020).

5. Конвенция Организации Объединённых Наций против коррупции: принята Резолюцией № 58/4 Генеральной Ассамблеи от 31 октября 2003 года. URL: https://www.un.org/ru/documents/decl_conv/conventions/corruption.shtml (дата обращения: 20.12.2020).

6. Федеральный закон от 08.03.2006 № 40-ФЗ «О ратификации Конвенции Организации Объединённых Наций против коррупции» // Российская газета. 2006. 21 марта.

7. Берестень В. И. Коррупция и её общественная опасность. Минск: РИВШ, 2005. 166 c.

8. Епифанов А. Е., Симон А. Л. Противодействие коррупции в международном сообществе (вопросы права) // Право и практика. 2011. № 1. C. $30-42$.

9. Кулуева Ф. Г. Национальная стратегия противодействия коррупции и национальный план противодействия коррупции // Наука, техника и образование. 2020. № 1. C. 71-75.

10. Конвенция Организации Объединённых Наций против транснациональной организованной преступности: принята Резолюцией № 55/25 Генеральной Ассамблеи от 15 ноября 2000 года // Бюллетень международных договоров. 2005. № 2. C. 3-33. 